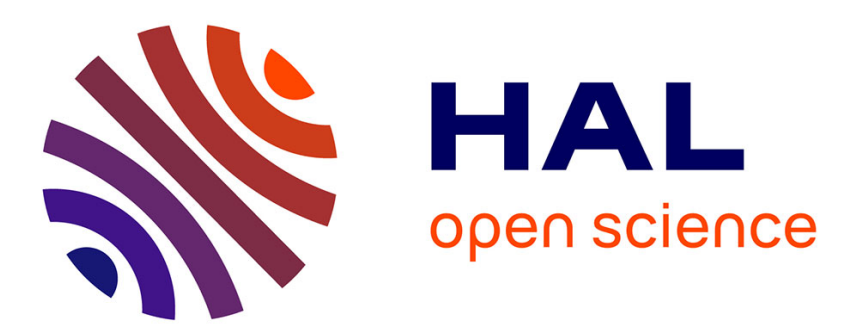

\title{
Effect of the discharge rate on the electrochemical properties of LaY2Ni9 hydrogen storage alloy
}

Yassine Ben Belgacem, Chokri Khaldi, Jilani Lamloumi, Hisasi Takenouti

\section{To cite this version:}

Yassine Ben Belgacem, Chokri Khaldi, Jilani Lamloumi, Hisasi Takenouti. Effect of the discharge rate on the electrochemical properties of LaY2Ni9 hydrogen storage alloy. Journal of Alloys and Compounds, 2015, 631, pp.7-14. 10.1016/j.jallcom.2015.01.074 . hal-01112474

\section{HAL Id: hal-01112474 https://hal.science/hal-01112474}

Submitted on 9 Jun 2015

HAL is a multi-disciplinary open access archive for the deposit and dissemination of scientific research documents, whether they are published or not. The documents may come from teaching and research institutions in France or abroad, or from public or private research centers.
L'archive ouverte pluridisciplinaire HAL, est destinée au dépôt et à la diffusion de documents scientifiques de niveau recherche, publiés ou non, émanant des établissements d'enseignement et de recherche français ou étrangers, des laboratoires publics ou privés. 


\title{
Effect of the discharge rate on the electrochemical properties of $\mathrm{LaY}_{2} \mathrm{Ni}_{9}$ \\ hydrogen storage alloy
}

\author{
Yassine Ben Belgacem ${ }^{\mathrm{a}}$, Chokri Khaldi ${ }^{\mathrm{a}}{ }^{*}$, Jilani Lamloumi ${ }^{\mathrm{a}}$, Hisasi Takenouti ${ }^{\mathrm{b}}$ \\ ${ }^{a}$ Equipe des Hydrures Métalliques, LMMP, ENSIT (Ex ESSTT), Université de Tunis, 5 \\ Avenue Taha Hussein, 1008 Tunis, Tunisia \\ ${ }^{\mathrm{b}}$ LISE, CNRS, UPMC Univ Paris06, Case 133, 4 Place Jussieu, 75252 Paris Cedex 05, France
}

\begin{abstract}
The use of new hydrogen absorbing alloys as negative electrodes in rechargeable batteries has allowed the consideration of nickel-metal hydride batteries to replace the conventional nickelcadmium alkaline or lead acid batteries. In this study the $\mathrm{LaY}_{2} \mathrm{Ni}_{9}$ hydrogen storage alloys was prepared and the effect of the discharge rate on the electrochemical properties of the active material was investigated. For this case, several electrochemical methods such as the galvanostatic charging and discharging, the constant potential discharge, and the potentiodynamic polarization are used to better understand the effect of the discharge rate on the behavior of the $\mathrm{LaY}_{2} \mathrm{Ni}_{9}$ electrode.
\end{abstract}

The decrease of the discharge rate, firstly, facilitates the activation of the alloy and other hand, causes the decrease of the drop potential that can be correlated with both the maximum discharge capacity and the cycle number of activation. After activation the electrochemical discharge capacity undergoes a rapid decay before slowing during a long cycling. A good stability and cycling lifetime are observed for $\mathrm{C} / 10$ rate. This degradation is mainly due to the corrosion of the electrode surface overlooked to the aggressive electrolyte (1M).

The corrosion current density at the first activation cycle increases as a function of the electrochemical cycling. This growth becomes faster when the discharge rate becomes smaller. 
The corrosion potential during the first activation cycles, and for all rates, undergoes an increase to the direction of the positive potential. For a long cycling and except of the $\mathrm{C} / 20$ rate, an oscillating stabilization of both the corrosion current density and potential are observed and is better for the $\mathrm{C} / 10$ rate which is in good agreement with the good holding to cycling for this medium rate.

Keywords: Nickel-metal hydride batteries; Electrochemical characterization methods, Discharge rate; Kinetic and corrosion parameters.

\section{Introduction}

Researches dealing with hydride forming intermetallics, such as $\mathrm{AB}_{\mathrm{n}}(\mathrm{A}$, rare earth or transition element, $\mathrm{B}$; transition element; $n=5,3,2$ or 1 ) [1-4], have attracted increasing interest in the last few years due to their ability to store reversibly large amounts of hydrogen near ambient pressure and room temperature. These remarkable properties allow using them for energy storage applications either as hydrogen tanks or as negative-electrode materials in alkaline batteries.

Compared to the conventional lead acid and nickel-cadmium batteries, the nickel-metal hydride battery has many advantages [5]. In fact, this kind of batteries does not cause any kind of contamination, has a long life cycle, a good charge-discharge kinetic and does not have any memory effect. However, the overall properties of $\mathrm{Ni}-\mathrm{MH}$ batteries should be improved to face the competition of Li-ion batteries used for the personal computer, the mobile phone and the video cameras. Recently, almost all of the commercial Ni-MH batteries are employing $\mathrm{AB}_{5}$-type alloys as negative electrode materials due to their good overall electrode properties [6-16].

For instance, in the search for new metal hydrides, recent attention has been dedicated to the family of $\mathrm{AB}_{3}$-intermetallics, e.g., some new pseudo-binary and ternary intermetallics such as 
$\mathrm{LaMg}_{2} \mathrm{Ni}_{9}$ [17], which have been shown to correspond to an intergrowth of $\mathrm{MgNi}_{2}$ and $\mathrm{RNi}_{5}$ layers. However Despite the large discharge capacity and high activity of these alloys, the accelerated degradation of the discharge capacity after only few cycles of charge and discharge is the main shortcoming against their commercial use in batteries.

The knowledge of the hydrogen storage properties of the binary compounds $\mathrm{LaNi}_{5}$ and $\mathrm{YNi}_{2}$ prompted us to focus our interest on the La-Y-Ni ternary system. The La-Y-Ni system has been investigated in the present work assuming the reaction: $\mathrm{LaNi}_{5}+2 \mathrm{YNi}_{2} \rightarrow \mathrm{LaY}_{2} \mathrm{Ni}_{9}$.

The $\mathrm{LaY}_{2} \mathrm{Ni}_{9}$ compound adopts a rhombohedral structure derived from the PuNi3-type one ( $R$-3mspace group) and it can be described as the intergrowth of $\mathrm{LaNi}_{5}$ (Haucke phase) and $\mathrm{YNi}_{2}$ (Laves phase). In this article, we describe the affect of the rate on the electrochemical proprieties of $\mathrm{LaY}_{2} \mathrm{Ni}_{9}$ alloy used as a negative electrode in $\mathrm{Ni}-\mathrm{MH}$ batteries.

\section{Experimental}

The $\mathrm{LaY}_{2} \mathrm{Ni}_{9}$ alloy was prepared by induction melting of the pure elements followed by an appropriate annealing at a temperature of $750^{\circ} \mathrm{C}$ to ensure a good homogeneity. The result of the metallographic examination, the electron probe microanalysis (EPMA) and the structure characterization by X-ray diffraction (XRD) of this alloy is given in table 1 . The structural characterization shows that this alloy is indexed in the PuNi3-type rhombohedral structure (space group R-3m) which can be described as a stacking of $\mathrm{CaCu}_{5}$ and $\mathrm{MgZn}_{2}$ units.

Table1. EPMA and XRD analysis of $\mathrm{LaY}_{2} \mathrm{Ni}_{9}$ alloy

\begin{tabular}{c|c|c|c|c}
\hline \multirow{2}{*}{ Alloy } & \multirow{2}{*}{ EPMA analysis } & \multicolumn{3}{|c}{ XRD analysis } \\
\cline { 3 - 5 } & & Cell parameters & Volume \\
\cline { 3 - 5 } & & $\mathrm{a}(\AA)$ & $\mathrm{c}(\AA)$ & $\mathrm{V}\left(\AA^{3}\right)$ \\
\hline $\mathrm{LaY}_{2} \mathrm{Ni}_{9}$ & $\mathrm{La}_{1.05} \mathrm{Y}_{1.98} \mathrm{Ni}_{8.97}$ & 5.0343 & 24.507 & 537.9 \\
\hline
\end{tabular}

The $\mathrm{LaY}_{2} \mathrm{Ni}_{9}$ ingot alloy was grounded mechanically and sieved (to less than $63 \mu \mathrm{m}$ ) in a glove box under an argon atmosphere [18]. The "latex" technology has been used for the 
electrode preparation [19]. Ninety percent of the alloy powder was mixed with $5 \%$ of carbon black to obtain a good conductivity and 5\% of polytetrafluoroethylen (PTFE) to give elasticity to the electrode to give elasticity to the electrode.

Two pieces of $0.5 \mathrm{~cm}^{2}$ of this latex have been pressed on each side of a nickel grid, playing the role of a current collector [20]. This assembly forms the negative electrode of Ni-MH battery. All the electrochemical measurements were performed at a room temperature in a conventional three electrodes open-air cell using a computer-controlled frequency response analyzer coupled directly with EC-Lab ${ }^{\circledR}$ V10.12 system constituted by a Potentiostat-GalvanostatEIS. A nickel mesh and an $\mathrm{Hg} / \mathrm{HgO}$ electrode have been used as a counter electrode and a reference electrode, respectively. The electrolyte consisted of $\mathrm{KOH}(1 \mathrm{M})$ solution, which paddled by a continuous flow of argon.

- Activation and a long cycling of the electrodes were realized by galvanostatically charging and discharging at different rates $(\mathrm{C} / 3, \mathrm{C} / 5, \mathrm{C} / 10$ and $\mathrm{C} / 20)$.

- The constant discharge potential (CPD) was applied after each cycle during a long cycling and at different rates $(\mathrm{C} / 3, \mathrm{C} / 5, \mathrm{C} / 10$ and $\mathrm{C} / 20)$ using a chronoamperometry method.

- The potentiodynamic polarization tests were carried out, after each cycle during a long cycling, at a scan rate of $1 \mathrm{mV} \mathrm{s}^{-1}$, the potential scan direction, is performed from $(-1200 \mathrm{mV})$ to $(-600 \mathrm{mV})$ versus $\mathrm{Hg} / \mathrm{HgO}$, to estimate the corrosion current density and the corrosion potential of the electrodes in $\mathrm{KOH}$ solution.

\section{Results and discussion}

\subsection{The activation and the long cycling of the $\mathrm{LaY}_{2} \mathrm{Ni}_{9}$ electrode at different discharge rates.}

Fig.1 and Fig.2 show the electrochemical discharge and the half charge and discharge potential curves, respectively, during the activation first cycles of the $\mathrm{LaY}_{2} \mathrm{Ni}_{9}$ electrode at different rates $(\mathrm{C} / 3, \mathrm{C} / 5, \mathrm{C} / 10$ and $\mathrm{C} / 20)$. 

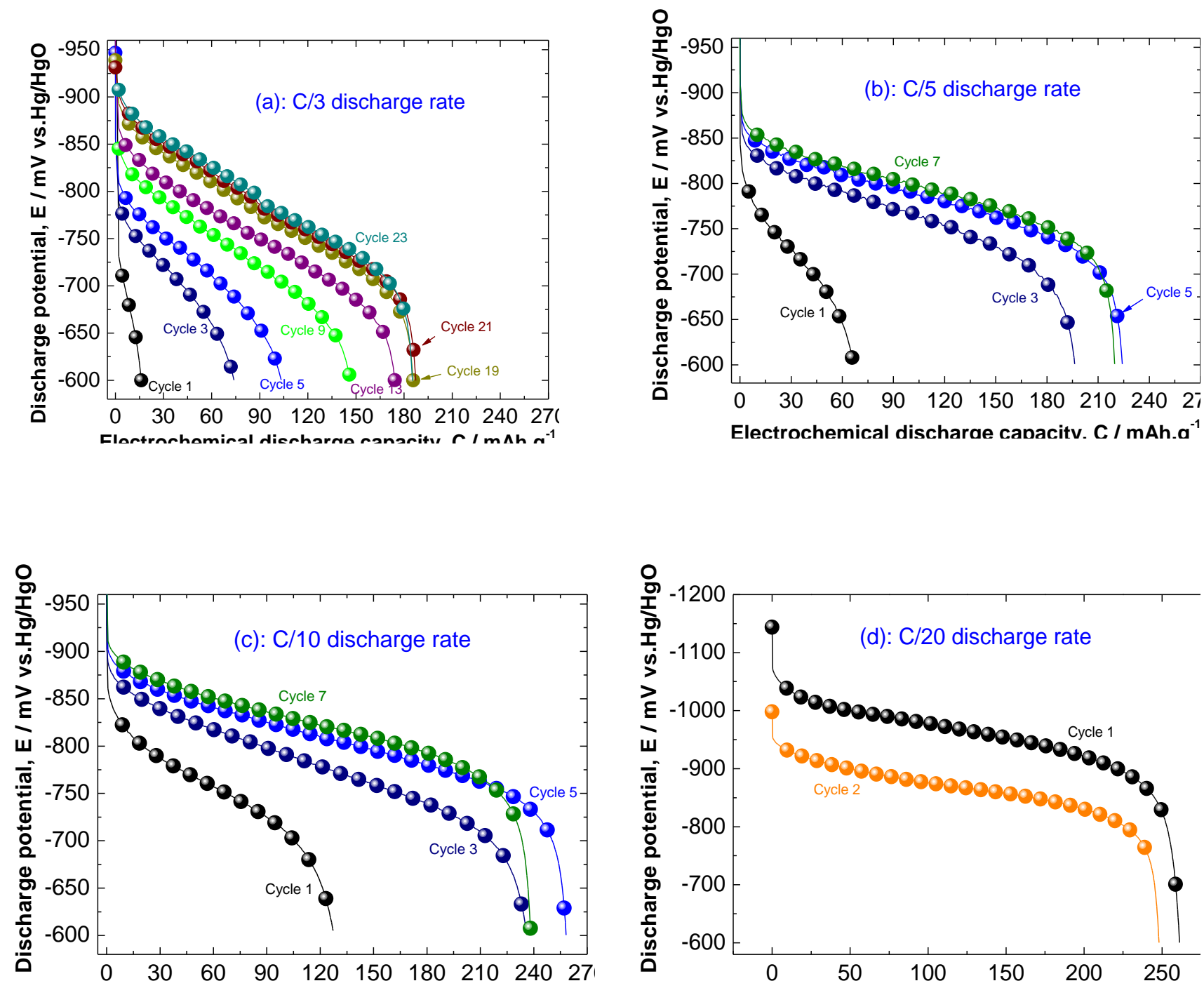

Electrochemical discharae canacitv. C / mAh.a ${ }^{-1}$

Electrochemical discharae canacitv. C / mAh.a

Fig.1. Evolution of the electrochemical discharge curves of the $\mathrm{LaY}_{2} \mathrm{Ni}_{9}$ electrodes during the first activation cycles at different rates: (a): $\mathrm{C} / 3$ rate; (b): $\mathrm{C} / 5$ rate, $(\mathrm{c}): \mathrm{C} / 10$ rate; (d): $\mathrm{C} / 20$ rate.
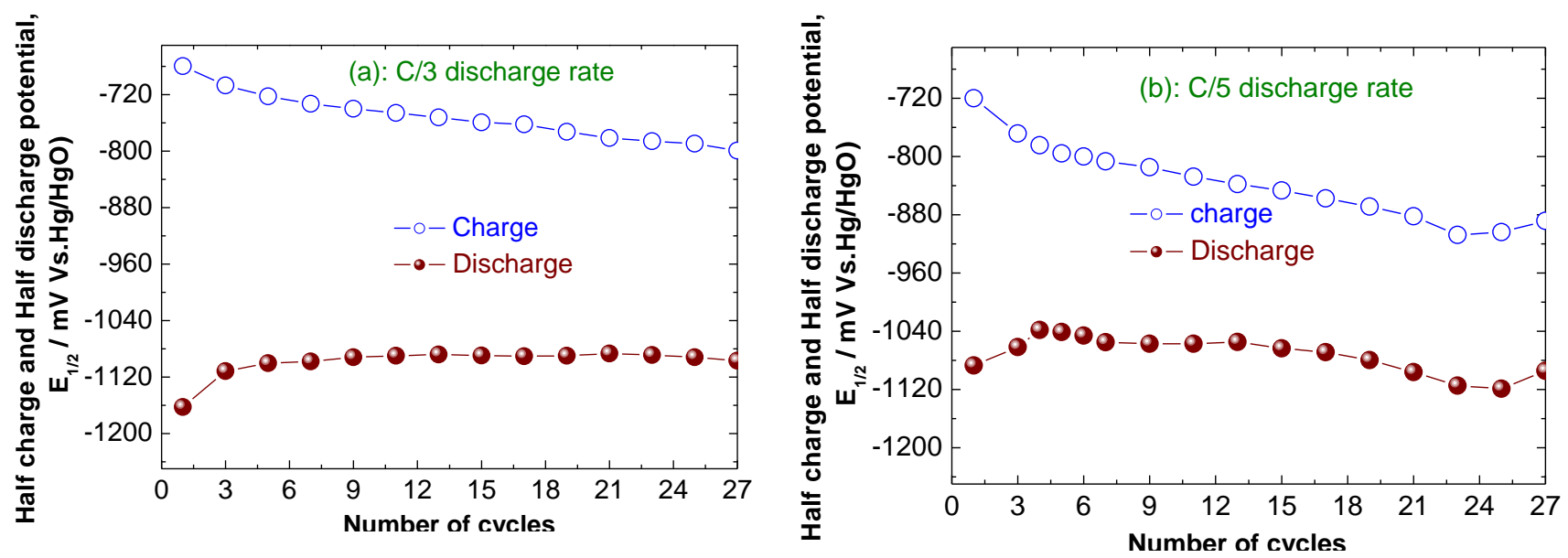

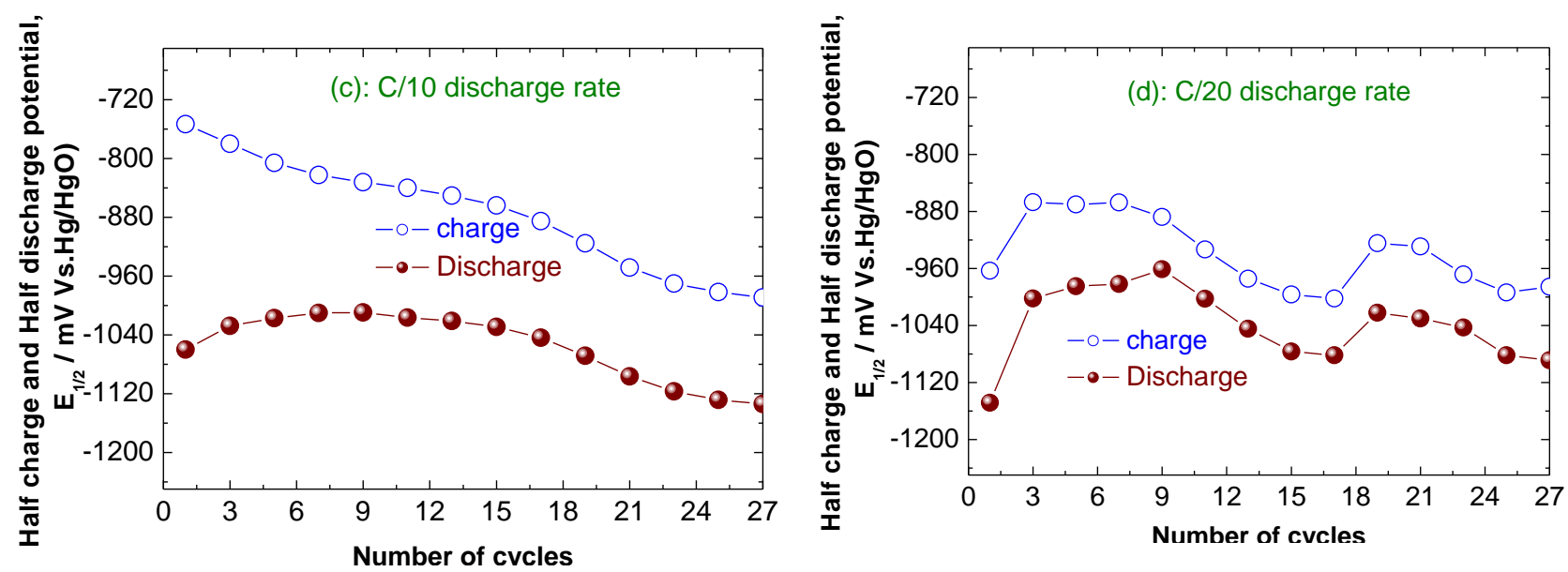

Fig.2. Evolution of the half charge and half discharge potential curves during the first activation cycles for the $\mathrm{LaY}_{2} \mathrm{Ni}_{9}$ electrode at different rates: (a): $\mathrm{C} / 3$ rate; (b): $\mathrm{C} / 5$ rate, (c): $\mathrm{C} / 10$ rate; $(\mathrm{d}): \mathrm{C} / 20$ rate.

In Table 2 we regrouped the cycle number of activation, the maximum discharge capacity and the drop potential, between the half charge and discharge potentials, of the $\mathrm{LaY}_{2} \mathrm{Ni}_{9}$ electrode at different rates.

Table 2. Activation cycle number, maximum discharge capacity and the drop potential (between the half charge and discharge potentials) of the $\mathrm{LaY}_{2} \mathrm{Ni}_{9}$ electrode at different rates. 


\begin{tabular}{|l|c|c|c|c|}
\hline & Régime C/3 & Régime C/5 & Régime C/10 & Régime C/20 \\
\hline Activation cycle number & 21 & 5 & 5 & 1 \\
\hline $\begin{array}{l}\text { Maximum discharge } \\
\text { capacity (mAh g })^{-1}\end{array}$ & 187 & 224 & 259 & 262 \\
\hline Drop potential (mV) & 308 & 205 & 147 & 71 \\
\hline
\end{tabular}

We note that the decrease of the discharge rate facilitates the activation of the alloy. Indeed, by going from the largest rate $(\mathrm{C} / 3)$ to the lowest one $(\mathrm{C} / 20)$, the necessary cycle number of activation of the alloy is reduced to only one cycle and the electrochemical discharge capacity undergoes an increase of $40 \%$.

The decrease of the drop potential with the decrease of the discharge rate can be correlated with both the maximum discharge capacity and the cycle number of activation. Indeed, the maximum discharge capacity and the drop potential values, for the largest rate $(\mathrm{C} / 3)$ and the lowest one (C/20), are $187 \mathrm{mAh} \mathrm{g}^{-1}$ (21 cycle of activation), $308 \mathrm{mV}$ and $262 \mathrm{mAh} \mathrm{g}^{-1}$ (one cycle of activation), $71 \mathrm{mV}$, respectively. Despite the observed fluctuation for the low rates, the found potential drop $(70 \mathrm{mV})$ indicates a good faradic efficiency and reaction reversibility related to the hydrogen insertion.

Fig. 3 presents the evolution of electrochemical discharge capacity with the cycle number during a long cycling at different discharge rates $(\mathrm{C} / 3, \mathrm{C} / 5, \mathrm{C} / 10$ and $\mathrm{C} / 20)$. 


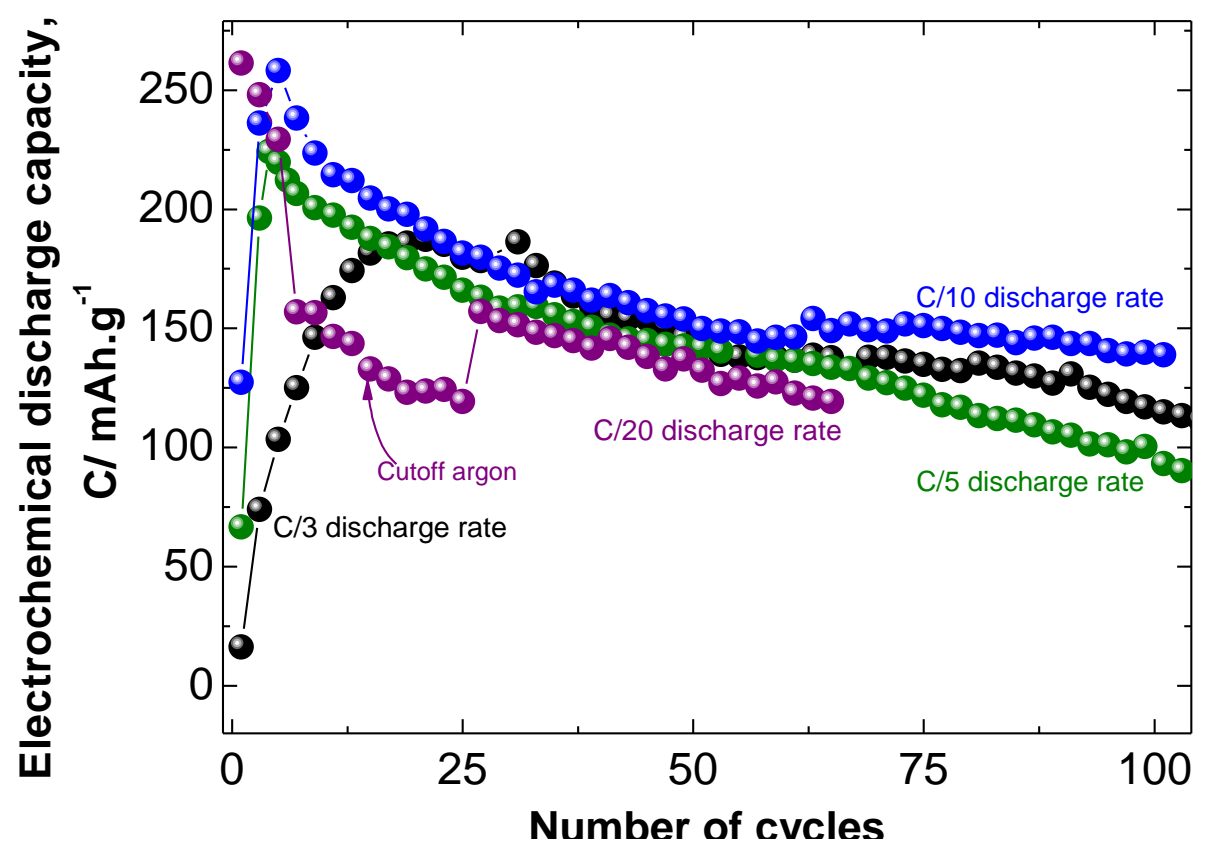

Fig.3. Evolution of the electrochemical discharge capacity with cycle number during a long cycling of the $\mathrm{LaY}_{2} \mathrm{Ni}_{9}$ electrode at different rates.

During the activation, the electrochemical discharge capacity reaches its maximum value of 187, 224, 259, $262 \mathrm{mAh} \mathrm{g}^{-1}$ after 21, 5, 5 and 1 cycle at $\mathrm{C} / 3, \mathrm{C} / 5, \mathrm{C} / 10$ and $\mathrm{C} / 20$ rate, respectively. After activation the electrochemical discharge capacity undergoes a rapid decay before slowing. A good held of cycling is observed beyond 50 cycles for $\mathrm{C} / 10$ rate.

The discharge capacity loss can be explained by the corrosion of the $\mathrm{LaY}_{2} \mathrm{Ni}_{9}$ electrode, in the $\mathrm{KOH}$ electrolyte, which will be discussed thereafter in the present work.

The cycling capacity retention is expressed by the following formula: $\left(\frac{C_{\mathrm{n}}}{C_{\max }}\right) \times 100$ Where $C_{\max }$ is the maximum discharge capacity and $C_{n}$ is the discharge capacity at the $n^{\text {th }}$ cycle. In table 2 we illustrated the cycling capacity retention values at 60 and 100 cycles.

Table 2: The cycling capacity retention, $\left(\frac{C_{\mathrm{n}}}{C_{\max m}}\right) \times 100$, calculated at 60 and 100 cycles at different rates of $\mathrm{LaY}_{2} \mathrm{Ni}_{9}$ electrode. 


\begin{tabular}{|c|c|c|c|c|c|}
\hline \multirow{2}{*}{ Rate } & \multirow{2}{*}{$\mathrm{C}_{\max }$} & \multicolumn{2}{|c|}{$\mathrm{n}=60$ cycles } & \multicolumn{2}{c|}{$\mathrm{n}=100$ cycles } \\
\cline { 3 - 6 } & & $\mathrm{C}_{60}$ & $\frac{\mathrm{C} 60}{\mathrm{Cmax}} \%$ & $\mathrm{C}_{100}$ & $\frac{\text { C100 }}{\text { Cmax }} \%$ \\
\hline $\mathrm{C} / 3$ & 187 & 136 & 72 & 117 & 62 \\
\hline $\mathrm{C} / 5$ & 224 & 136 & 60 & 100 & 44 \\
\hline $\mathrm{C} / 10$ & 259 & 146 & 56 & 140 & 54 \\
\hline $\mathrm{C} / 20$ & 262 & 127 & 48 & - & - \\
\hline
\end{tabular}

At $60^{\text {th }}$ cycle the discharge capacity retention increase with the discharge rate. The same remark is reported at 100th cycle except of $\mathrm{C} / 10$ discharge rate. Indeed, the discharge capacity retention at this rate has the same value at 60 and $100^{\text {th }}$ cycle $(\sim 55 \%)$ by against it decreases from 72 to $62 \%$ and 60 to $44 \%$ for $\mathrm{C} / 3$ and $\mathrm{C} / 5$ rate, respectively.

The degradation of the electrochemical discharge capacity is mainly due to the corrosion of the electrode surface overlooked to the aggressive electrolyte [21]. At $\mathrm{C} / 10$ rate this degradation remains minimum, indeed, a good stability and cycling lifetime are observed.

\subsection{Evolution of $\left(\mathrm{D}_{\mathrm{H}} / \mathrm{a}^{2}\right)$ during a long cycling of $\mathrm{LaY}_{2} \mathrm{Ni}$ g electrode at different}

\section{discharge rates}

The ratio of hydrogen diffusion coefficient in the bulk of the $\mathrm{LaY}_{2} \mathrm{Ni}_{9}$ alloy by the square of the average particle radius of this alloy, during a long cycling and at different discharge rates, $\frac{D_{\mathrm{H}}}{a^{2}}$, is determined through the constant potential discharge (CPD) method. Fig. 4 shows the semi-logarithmic plots of anodic current vs. the time response of the $\mathrm{LaY}_{2} \mathrm{Ni}_{9}$ alloy at different cycles and discharge rates $(\mathrm{C} / 3, \mathrm{C} / 5, \mathrm{C} / 10$ and $\mathrm{C} / 20$ rate). 

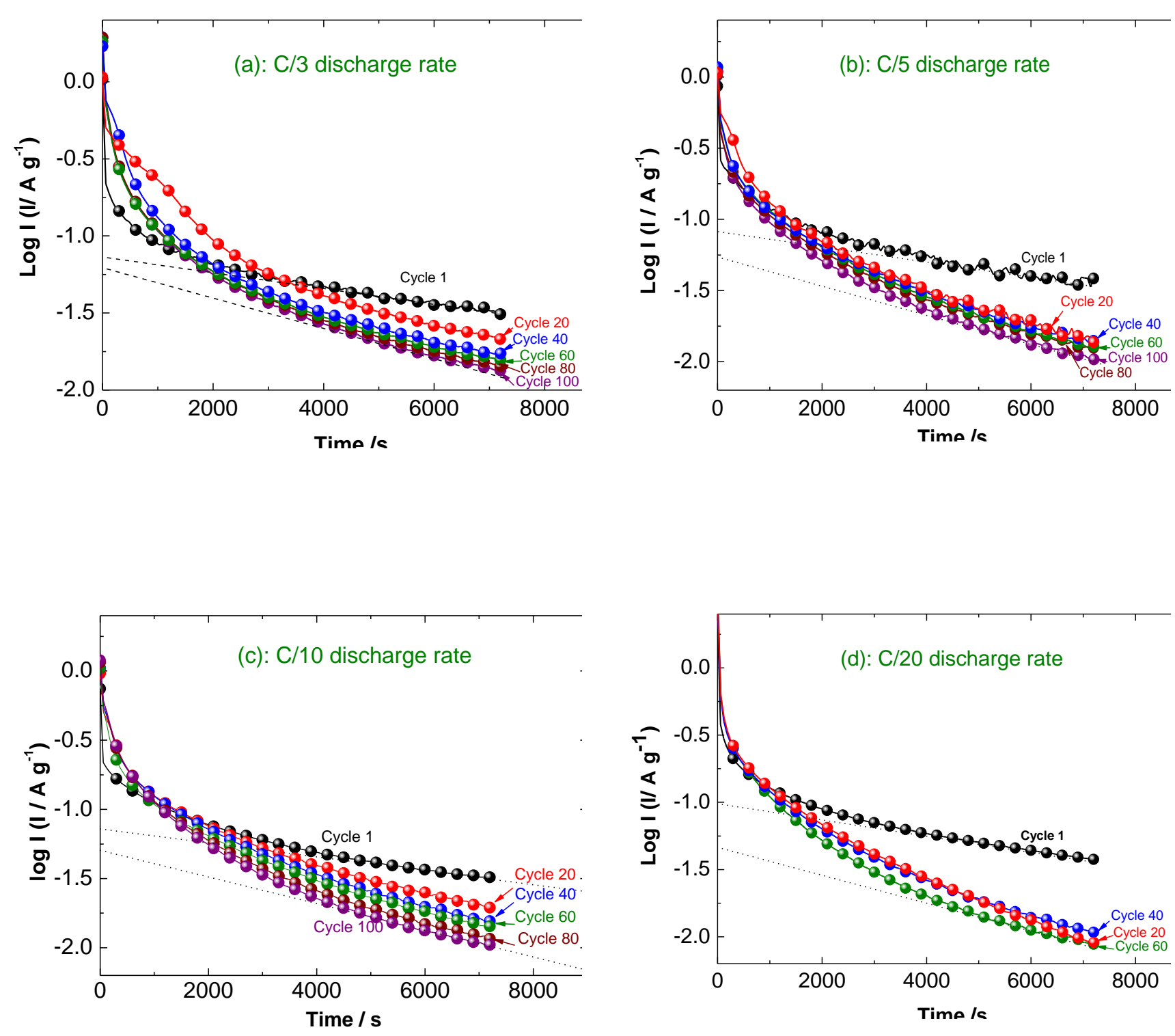

Fig.4. Typical potentiostatic curves of the $\mathrm{LaY}_{2} \mathrm{Ni}_{9}$ electrode for some cycles at constant potential $-0.6 \mathrm{~V}$ and at different discharge rates.

It can be seen that after the application of the overpotential, the current-time response can be divided into two time domains proposed by Nishina et al. [22]. In the first time region, the current rapidly decreased due to a consumption of hydrogen on the surface. However, in the second time region, the current slowly declined in a linear fashion. In this case, hydrogen was supplied from the bulk of the alloy in proportion to the concentration gradient of hydrogen 
atoms with time. According to the model of Zheng et al. [23], the ratio, $\frac{D_{\mathrm{H}}}{a^{2}}$, can be estimated through the slope of the linear region of the corresponding plots by the following formula:

$\log I=\log \left\{\frac{6 F D_{\mathrm{H}}}{d a^{2}}\left(C_{0}-C_{\mathrm{s}}\right)\right\}-\frac{\pi^{2} D_{\mathrm{H}}}{2.303 a^{2}} t$

wherein $D_{\mathrm{H}}$ is the hydrogen diffusion coefficient $\left(\mathrm{cm}^{2} \mathrm{~s}^{-1}\right), a$ is the radius of the spherical particle $(\mathrm{cm}), I$ is the diffusion current density $\left(\mathrm{mA} \mathrm{g}^{-1}\right), C_{\mathrm{o}}$ is the initial hydrogen concentration in the bulky alloy $\left(\mathrm{mol} \mathrm{cm} \mathrm{cm}^{-3}\right), C_{\mathrm{s}}$ is the hydrogen concentration on the surface of the alloy particles $\left(\mathrm{mol} \mathrm{cm}{ }^{-3}\right), F$ is the Faraday constant $\left(96487 \mathrm{C} \mathrm{mol}^{-1}\right), d$ is the density of the hydrogen storage alloy $\left(\mathrm{g} \mathrm{cm}^{-3}\right)$, and $t$ is the discharge time (s). According to the given Eq. (1), knowing the slope of the linear region of the corresponding plots, $\frac{\operatorname{dlog}(l)}{\mathrm{d} t}$, the ratio, $\frac{D_{\mathrm{H}}}{a^{2}}$, of the intermetallic electrode can be calculated, for each cycle at different discharge rates, according to the following equation:

$\frac{D_{\mathrm{H}}}{a^{2}}=-2 \cdot \frac{303}{\pi^{2}} \frac{\mathrm{d} \log (l)}{\mathrm{d} t}$

(2)

Fig. 5 shows the evolution of the ratio, $\frac{D_{\mathrm{H}}}{a^{2}}$, as a function of a long cycling at different discharge rates. 


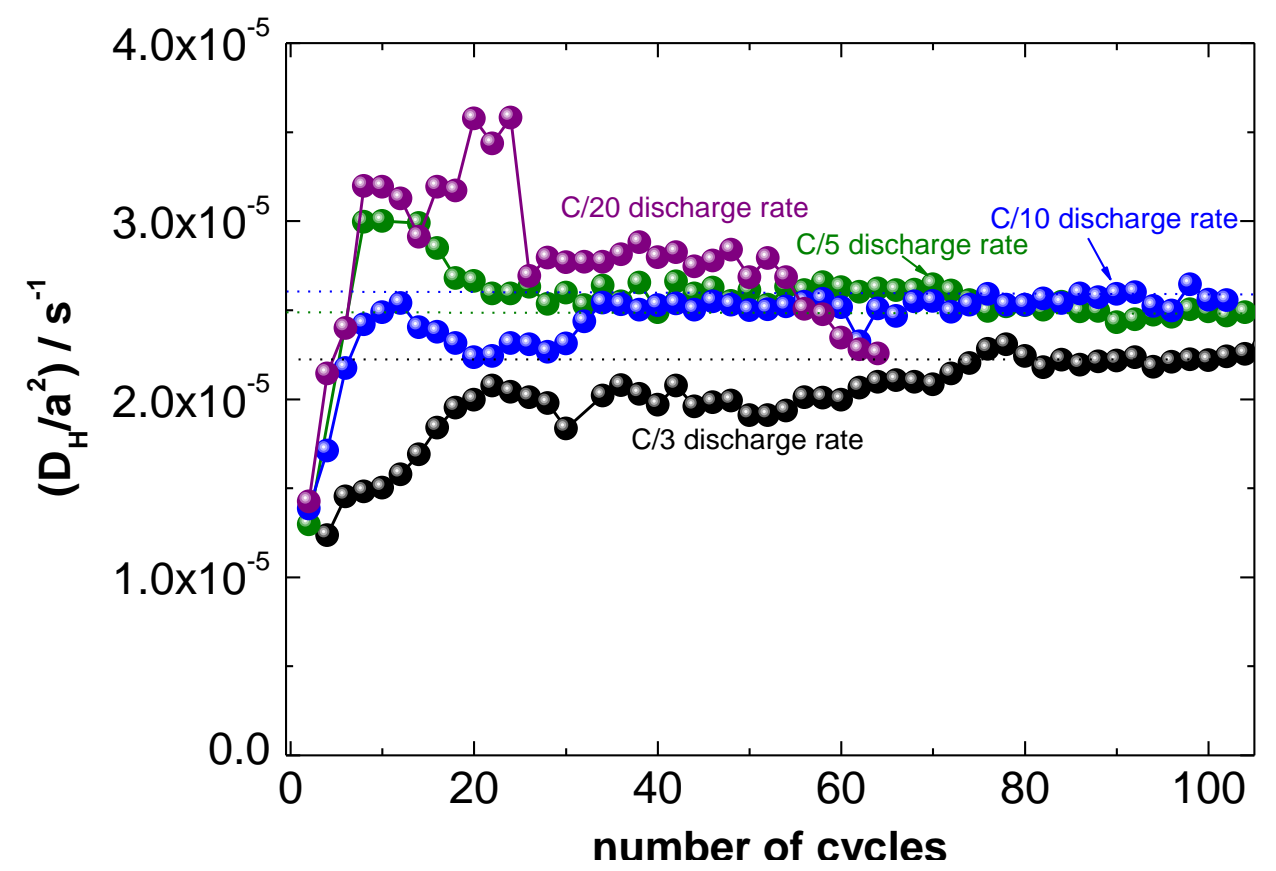

Fig.5. Evolution of the ratio $\left(\mathbf{D}_{\mathrm{H}} / \mathrm{a}^{2}\right)$, during a long cycling at different discharge rates.

The ratio, $\frac{D_{\mathrm{H}}}{a^{2}}$, firstly, undergoes an increase during the first cycles from $1.22 \times 10^{-5} \mathrm{~s}^{-1}$ to $2.10 \times 10^{-5} \mathrm{~s}^{-1}$ at the 22 th cycle, $1.30 \times 10^{-5} \mathrm{~s}^{-1}$ to $3 \times 10^{-5} \mathrm{~s}^{-1}$ at the 10 th cycle, $1.4 \times 10^{-5} \mathrm{~s}^{-1}$ to $2.52 \times 10^{-5} \mathrm{~s}^{-1}$ at the 12 th cycle and $1.41 \times 10^{-5} \mathrm{~s}^{-1}$ to $3.20 \times 10^{-5} \mathrm{~s}^{-1}$ at the 10 th cycle for the $\mathrm{C} / 3$, $\mathrm{C} / 5, \mathrm{C} / 10$ and $\mathrm{C} / 20$ rate, respectively. Then decreases gradually before stabilizing around the values $2.23 \times 10^{-5}, 2.49 \times 10^{-5}$ and $2.60 \times 10^{-5} \mathrm{~s}^{-1}$ during a long cycling for $\mathrm{C} / 3, \mathrm{C} / 5, \mathrm{C} / 10$ rate, respectively, except of the $C / 20$ rate that keeps an accentuated continual decay $\left(2.26 \times 10^{-5} \mathrm{~s}^{-}\right.$ ${ }^{1}$.at $64^{\text {th }}$ cycle).

A correlation was observed between the electrochemical capacity and the ratio of $\frac{D_{\mathrm{H}}}{a^{2}}$ during the first cycles of activation. Indeed, previous studies [24,25] showed that during the activation the absorbed hydrogen in the alloy causes the fragmentation and the cracking of the 
electrode, leading to the consequent increase of the active surface which facilitates the absorption and diffusion of hydrogen.

Fig. 6 shows the SEM micrographs of the investigated intermetallic electrodes taken immediately before and after the electrochemical tests at different discharge rates $(\mathrm{C} / 3, \mathrm{C} / 5$, $\mathrm{C} / 10$ and $\mathrm{C} / 20$ rate). According to a scanning electron microscopy (SEM) analysis, the average particle radius of the $\mathrm{LaY}_{2} \mathrm{Ni}_{9}$ electrodes after the electrochemical tests were estimated to be $37,23,23$ and $15 \mu \mathrm{m}$ for $\mathrm{C} / 3, \mathrm{C} / 5, \mathrm{C} / 10$ and $\mathrm{C} / 20$ rate, respectively. The hydrogen diffusion coefficient $D_{\mathrm{H}}$ in the bulky alloy is estimated to be $3.05 \times 10^{-10}, 1.32 \times 10^{-10}$, $1.37 \times 10^{-10}$ and $5.10 \times 10^{-11} \mathrm{~cm}^{2} \mathrm{~s}^{-1}$ for $\mathrm{C} / 3, \mathrm{C} / 5, \mathrm{C} / 10$ and $\mathrm{C} / 20$ rate, respectively, after a long cycling. 


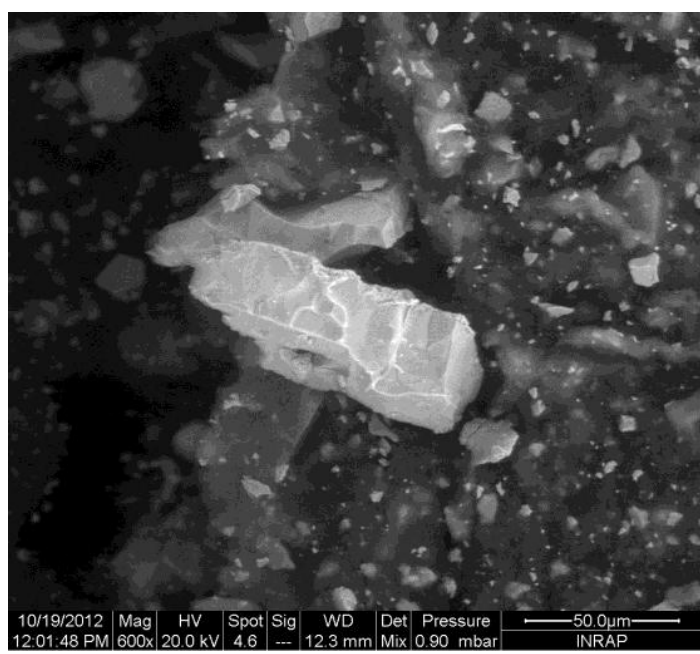

(a): Before electrochemical tests
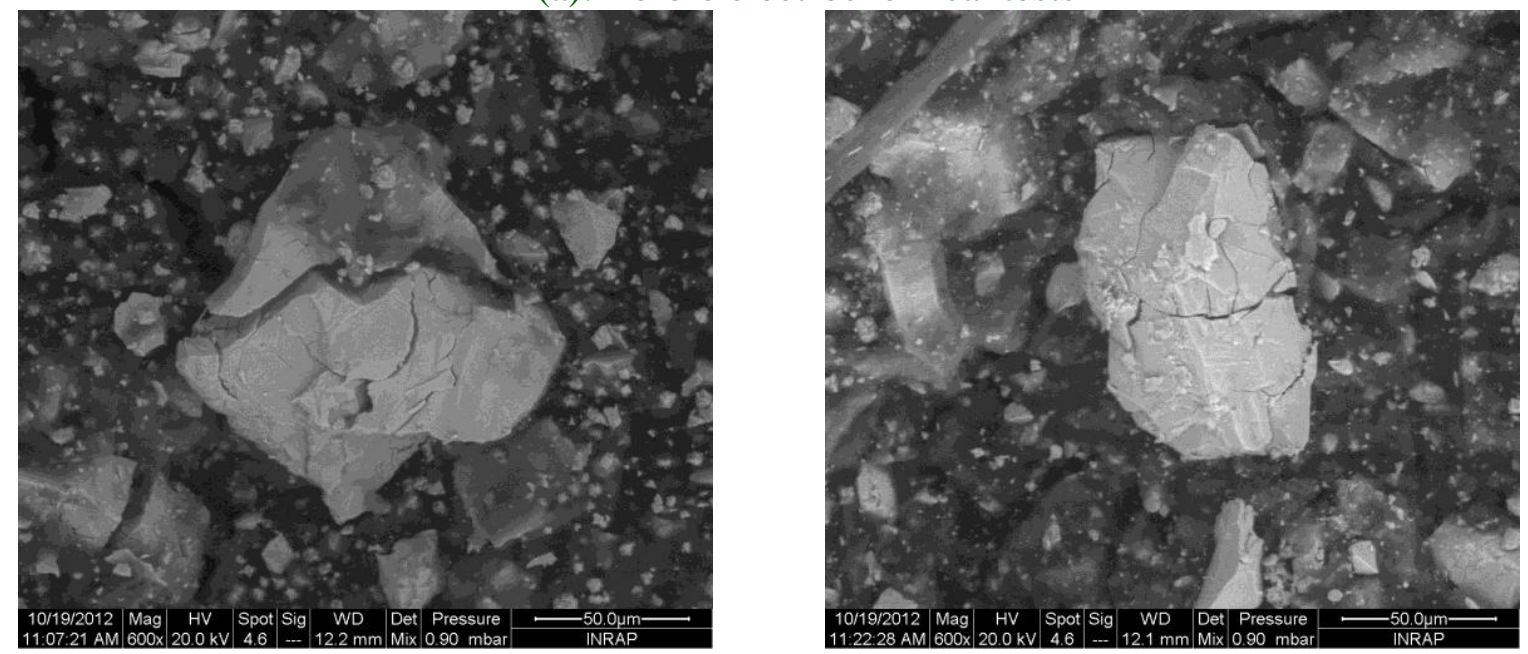

(b): $\mathrm{C} / 3$ discharge rate after electrochemical tests

(c): $\mathrm{C} / 5$ discharge rate after electrochemical

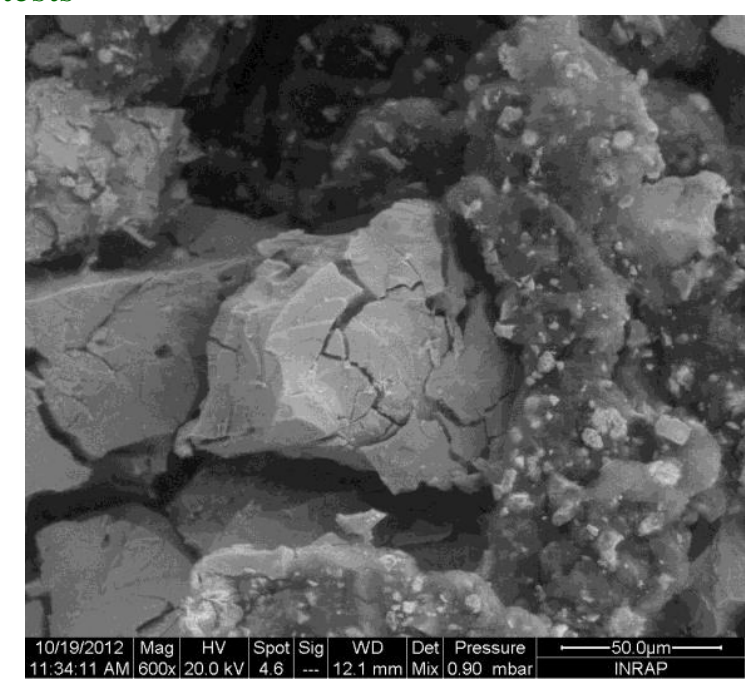
tests

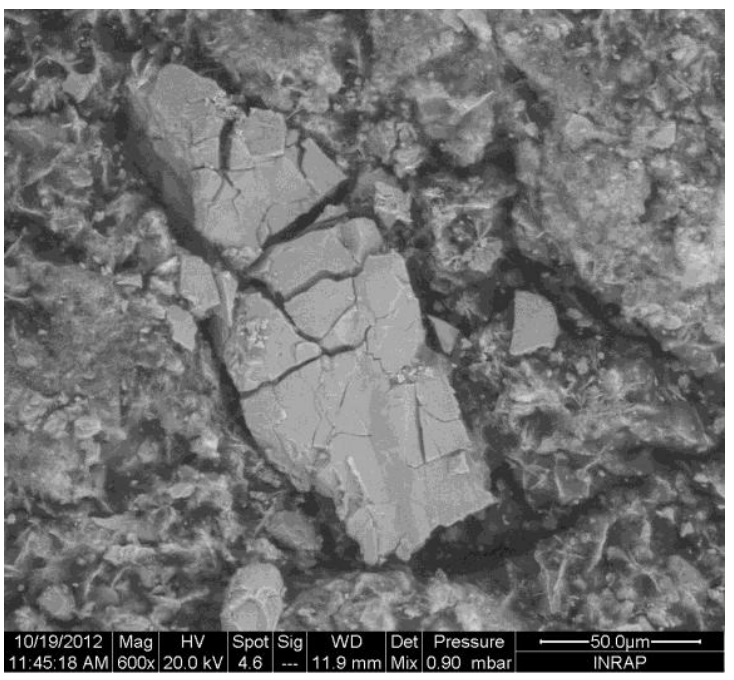

(d): C/10 discharge rate after electrochemical tests

(e): $\mathrm{C} / 20$ discharge rate after electrochemical tests

Fig.6 Scanning electron micrographs of the $\mathrm{LaY}_{2} \mathrm{Ni}_{9}$ electrode: (a): before electrochemical tests; (b), (c), (d) and (e): after electrochemical tests, respectively for C/3, C/5, C/10 and C/20 rate. 


\subsection{Evolution of the corrosion parameters during a long cycling of the $\mathrm{LaY}_{2} \mathrm{Ni}_{9}$ electrode at different discharge rates}

The study of the corrosion behavior of the $\mathrm{LaY}_{2} \mathrm{Ni}_{9}$ electrode during a long cycling and at different rates was performed through the voltammetry cyclic technique. This method consists to apply a linear potential scan rate of $1 \mathrm{mV} \mathrm{s}^{-1}$, on the $\mathrm{LaY}_{2} \mathrm{Ni}_{9}$ negative electrode, after each cycle of charge and discharge, during a long cycling and at different discharge rates. The obtained voltammograms at different discharge rates and during a long cycling, are treated by the first Stern-Geary method using EC-Lab software in order to draw the potentiodynamic polarization curves (or Tafel curves) [26,27].

Fig.7. shows the potentiodynamic polarization curves of the $\mathrm{LaY}_{2} \mathrm{Ni}_{9}$ electrode during activation and at different discharge rate. 

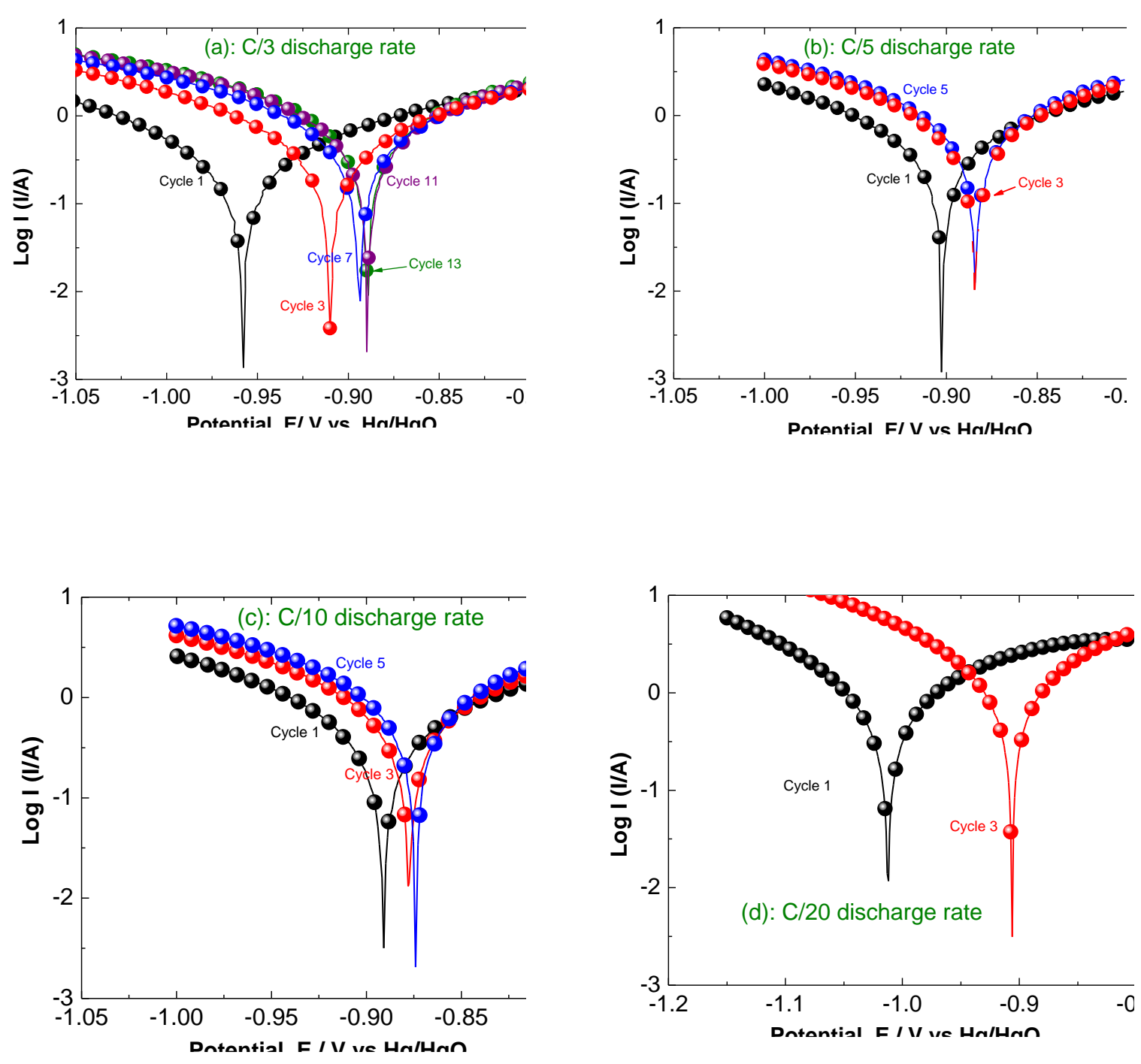

Fig.7. typical Potentiodynamic polarization curves of $\mathrm{LaY}_{2} \mathrm{Ni}_{9}$ electrode during activation and at different discharge rates: (a): $\mathrm{C} / 3,(\mathrm{~b}): \mathrm{C} / 5,(\mathrm{c}): \mathrm{C} / 10$ and (d): $\mathrm{C} / 20$ rate.

During the activation, the Tafel curves shift towards more positive direction, i.e., except of the $\mathrm{C} / 20$, the corrosion potential is more positive with decreasing the discharge rate. Indeed, the corresponding values are about of $-890,-884,-874$ and $-891 \mathrm{mV}$, respectively, for $\mathrm{C} / 3, \mathrm{C} / 5$, $\mathrm{C} / 10$ and $\mathrm{C} / 20$ rate. 
The corrosion current densities and potentials, through fitting the experimental results to the Tafel equation and by the Stern-Geary methods using EC-Lab software, are represented as a function of number of cycles in Fig. 8 and Fig.9, respectively.

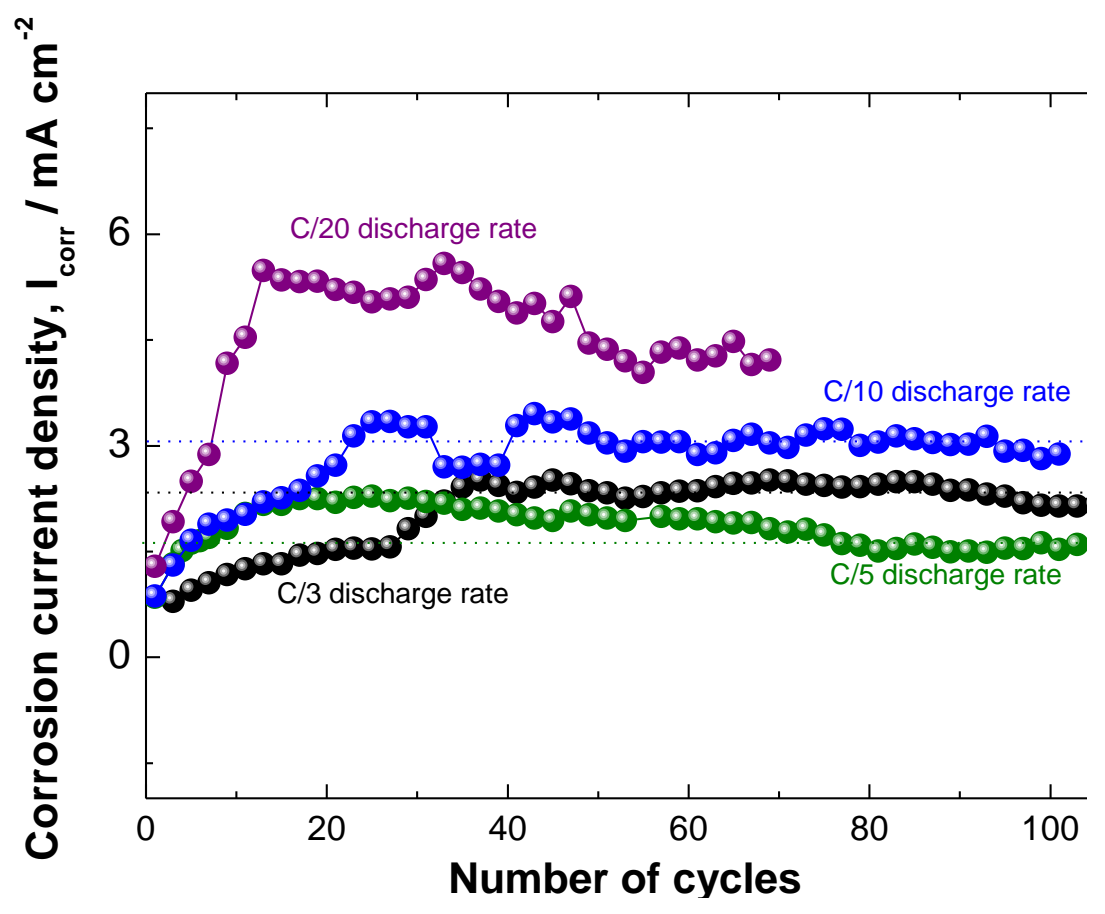

Fig.8. Evolution of the corrosion current density of the $\mathrm{LaY}_{2} \mathrm{Ni}_{9}$ electrode during a long cycling at different discharge rates.

The corrosion current density at the first activation cycle increases as a function of the electrochemical cycling. This growth becomes faster when the discharge rate becomes smaller. Indeed, for the lowest discharge rate corresponding to a long discharge time, the contribution of the parasite reactions due to the corrosion phenomenon become more dominant.

Beyond a certain number of cycles, and for the $\mathrm{C} / 3, \mathrm{C} / 5$ and $\mathrm{C} / 10$ rates, the corrosion current density undergoes a slight decrease during cycling. Except of the $\mathrm{C} / 20$ rate, an oscillating stabilization is observed and is better for the $\mathrm{C} / 10$ rate. These results are correlated with the 
evolution of the electrochemical discharge capacity and the ratio $\left(\mathbf{D}_{\mathrm{H}} / \mathrm{a}^{2}\right)$, during a long cycling at different rates.

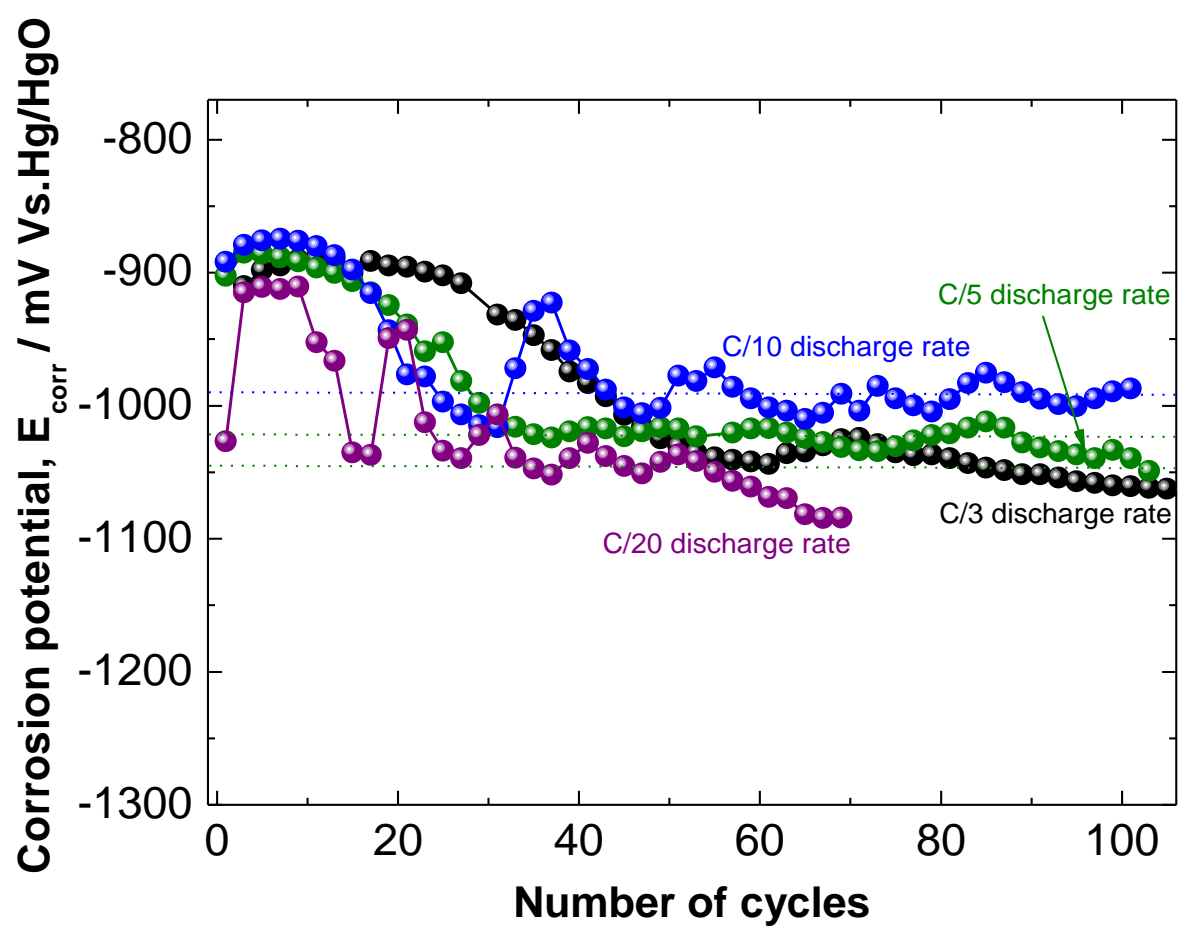

Fig.9. Evolution of the corrosion potential of the $\mathrm{LaY}_{2} \mathrm{Ni}_{9}$ electrode during a long cycling at different discharge rates.

The corrosion potential during the first activation cycles, and for all rates, undergoes an increase to the direction of the positive potential to reach the maximum values of, $-887,-883$, -871 and $911 \mathrm{mV}$ respectively for $\mathrm{C} / 3, \mathrm{C} / 5, \mathrm{C} / 10$ and $\mathrm{C} / 20$ discharge rates.

This evolution is correlated with the activation phenomenon, knowing that the cycling plays a role of pickling the surface of the electrode, that is to say the removal of a continuous manner of oxides from the surface of the electrode, engendering a reduction of the thickness of the layer of corrosion products.

For a long cycling and except of the $\mathrm{C} / 20$ rate, an oscillating stabilization of the corrosion potential around an average values of $-1043,-1019,-994 \mathrm{mV}$, respectively, for $\mathrm{C} / 3, \mathrm{C} / 5, \mathrm{C} / 10$ discharge rates are observed and is better for the $\mathrm{C} / 10$ rate which is in good agreement with the good holding to cycling for this medium rate 


\section{Conclusion}

In this present work, we studied in details as the effect of the discharge rate on the electrochemical properties of the $\mathrm{LaY}_{2} \mathrm{Ni}_{9}$ used as a negative electrode in nickel-metal hydride batteries. To carry out this work, the evolution of the electrochemical capacity, the ratio $\frac{D_{\mathrm{H}}}{a^{2}}$, and the corrosion current density and potential, during a long cycling and at different rates, were determined.

During the first cycle of activation and for the entire discharge rate, the evolution of all the kinetic and corrosion parameters shows a good correlation. Knowing that the cycling plays a role of pickling the surface of the electrode, that is to say the removal of a continuous manner of oxides from the surface of the electrode, engendering a reduction of the thickness of the layer of corrosion products and facilitates the hydrogen diffusion in the bulk of the alloy.

During a long cycling, this same correlation is observed and the $\mathrm{C} / 10$ medium rate presents the best stability and cycling lifetime.

Acknowledgments: The authors would like to express their gratefulness towards Mr. M. Latroche (LCMTR, CNRS, France, CMCU PHC Utique: 10G1208) for having given them the opportunity to prepare the alloys in their laboratory. 


\section{References}

[1] G. Sandrock, S. Suda, L. Schlapbach, in: L. Schlapbach (Ed.), Hydrogen in Intermetallic Compounds II, Topics in Applied Physics, Vol. 67, Springer, 1992, p. 197, Ch. 5.

[2] G. Sandrock, S. Suda, L. Schlapbach, in: L. Schlapbach (Ed.), Hydrogen in Intermetallic Compounds II, Topics in Applied Physics, Vol. 67, Springer, 1992, p. 197, Ch. 5.

[3] M. Tliha, C. Khaldi, S. Boussami, N. Fenineche, O. El-Kedim, H. Mathlouthi, J. Lamloumi, J Solid State Electrochem, 18 (2014) 577-593

[4] T. Sakai, M. Matsuoka, C. Iwakura, in: K.A. GschneidwerJr., L. Eyring (Eds.), Handbook on the Physics and Chemistry of Rare Earth, Vol. 21, Elsevier, 1995, p. 135.

[5] T. Sakai, K. Muta, H. Miyamura, N. Kuriyama, H. Ishikawa, in: D.A. Corrigan, S. Srinivasan (Eds.), Proc. Symp. Hydrogen Storage Materials, Batteries and Electrochemistry, Vol. 92-95, The Electrochemical Society, Pennington, NJ, 1992, p. 59.

[6] C. Khaldi, H. Mathlouthi, J. Lamloumi, A. Percheron-Guégan, Journal of Alloys and Compounds, 360 (2003) 266-271.

[7] C. Khaldi, H. Mathlouthi, J. Lamloumi, A. Percheron-Guégan, , International Journal of Hydrogen Energy, 29 (2004) 307- 311.

[8] H. Mathlouthi, C. Khaldi, M. Ben Moussa, J. Lamloumi, A. Percheron-Guégan, Journal of Alloys and Compounds, 375 (2004) 297-304.

[9] C. Khaldi, H. Mathlouthi, J. Lamloumi, A. Percheron-Guégan, Journal of Alloys and Compounds, 384 (2004) 249-253.

[10] M. Ben Moussa, M. Abdellaoui, C. Khaldi, H. Mathlouthi, J. Lamloumi, A. PercheronGuégan, Journal of Alloys and Compounds, 399 (2005) 264-269.

[11] M. Tliha, H. Mathlouthi, C. Khaldi, J. Lamloumi, A. Percheron-Guégan, Journal of Power Sources, 160 (2006) 1391-1394. 
[12] C. Khaldi , H. Mathlouthi, J. Lamloumi, A. Percheron-Guégan, Journal of Physics \& Chemical News, 29 (2006) 76-80.

[13] M. Tliha, C. Khaldi, H. Mathlouthi, J. Lamloumi, A. Percheron-Guégan, Journal of Alloys and Compounds, 440 (2007) 323-327.

[14] C. Khaldi , H. Mathlouthi, J. Lamloumi, A. Percheron-Guégan, Journal of Physics \& Chemical News, 40 (2008) 139-142.

[15] C. Khaldi, H. Mathlouthi, J. Lamloumi, Journal of Alloys and Compounds, 469 (2009) $464-471$.

[16] Chokri Khaldi, Hamadi Mathlouthi, Jilani Lamloumi, Journal of Alloys and Compounds, 479 (2009) 284-289.

[17] B.D. Dunlap, P.J. Viccaro, G.K. Shenoy, J. Less-Common Met. 74 (1980) 75-79.

[18] C. Khaldi, Éditions Universitaires Européennes, Etude électrochimique des alliages $\mathrm{LaNi}_{3.55} \mathrm{Mn}_{0.4} \mathrm{Al}_{0.3} \mathrm{Co}_{0.75-\mathrm{x}} \mathrm{Fe}_{\mathrm{x}}$ - Application aux accumulateurs nickel-métal hydrure, ISBN: 978-613-1-59802-9 (2011).

[19] H. Mathlouthi, J. Lamloumi, M. Latroche, A. Percheron-Guégan, Ann. Chim. Sci. Mat. 22 (1997) 241.

[20] C.-J. Li, F.-R. Wang, W.-H. Cheng, W. Li, W.-T. Zhao, J. Alloys Compd. 315 (2001) $218-223$.

[21] C. Khaldi, Éditions Universitaires Européennes, Caractérisation électrochimiques des électrodes négatives - Application aux batteries nickel-metal hydrure,ISBN: 978-3-84179252-5 (2014).

[22] T. Nishina, H. Ura, I. Uchida, J Electrochem Soc, 144 (1997) 1273-1277.

[23] G. Zheng, B.N. Popov, R. E. White, J Electrochem Soc,142 (1995) 2695-2698.

[24] C. Khaldi, S. Boussami, B. Ben Rejeb, H. Mathlouthi, J. Lamloumi, Mater Sci Eng B, 175 (2010) 22-28. 
[25] S. Boussami, C. Khaldi, J. Lamloumi, H. Mathlouthi, H. Takenouti, Electrochim Acta, 69 (2012) 203-208.

[26] C. Khaldi, S. Boussami, M. Tliha, S. Azizi, N. Fenineche, O. El-Kedim, H. Mathlouthi, J. Lamloumi, Journal of Alloys and Compounds, 574 (2013) 59-66

[27] Y. B. Belgacem, C. Khaldi, S. Boussami H. Mathlouthi, J. Lamloumi J Solid State Electrochem, DOI: 10.1007/s10008-014-2448-5 (2014). 